\title{
FOGAZATTERVEZŐ PROGRAM FUNKCIÓINAK BEMUTATÁSA ÉS TOVÁBBI FEJLESZTÉSI LEHETŐSÉGEI
}

\author{
Várkuli Miklós Gábor \\ PhD hallgató, Miskolci Egyetem, Gép-és Terméktervezési Intézet \\ 3515 Miskolc, Miskolc-Egyetemváros, e-mail:machvmg@uni-miskolc.hu
}

\begin{abstract}
Absztrakt
Jelen cikkben bemutatunk egy szabad szoftverként fejlesztett méretezö és analitikai tervezö szoftvert, mely kúpkerekek geometriai méretezésére és elemzésére alkalmas. A bemutatott program komoly alternativát jelent a jelenleg kereskedelemben beszerezhetö költséges szoftverekkel szemben. A szoftver modularitása és nyilt forráskódja korlátlan fejlesztési lehetöségeket és rugalmas, jól adaptálható eszközt ad minden kutató kezébe.
\end{abstract}

Kulcsszavak: szimuláció, moduláris programozás, geometriai méretezés

\begin{abstract}
In this article we are introducing a free software designed for analytical and geometrical calculation of bevel gear pairs. This software is a good alternative compared to it's costly commercial competitors. The modularity and open source code of our program provides an endless upgrade possibility and it gives a flexible and adaptable tool for every researcher.
\end{abstract}

Keywords: simulation, modular programming, geometrical sizing

\section{Bevezetés}

A számítógépek rohamos fejlődésével egyre összetettebb és jobban automatizált gyártórendszereket fejlesztenek ki. A fejlesztések az egyre nagyobb automatizálás irányába haladnak, hogy csökkentsék a szükséges emberi munkaerőt, ezzel csökkentve az emberi hiba lehetőségét és növelve a termelékenységet. Az automatizálás mellett egyre nagyobb hangsúlyt kapnak az integrált gyártórendszerek, ahol direkt összeköttetés van a tervezőszoftverek és a gyártó rendszerek között, ezzel azonnali gyártásra nyílik lehetőség a frissen elkészült 3D modellekből. Ezek a rendszerek rengeteg értékes időt takarítanak meg az automatizáltságuk révén, de van egy komoly hátrányuk is. A rendszert és a gyártó berendezéseket gyártó cégek egyre inkább ipari titokként kezelik a gyártási paraméterek beállításához szükséges számítási eljárásokat, komolyan limitálva a kezelőszervek által megengedett külső beavatkozást. Ennek eredményeképp az elkészült termék geometriai paraméterei csak nagyon kis mértékben ismertek. Ez a tény megnehezíti a hibaanalízist, az optimalizálást és az újratervezési folyamatokat. Az általunk fejlesztett program erre kínál egy alternatívát. A szoftver célja egy széles felhasználási spektrumú rendszer kialakítása, melyben a felhasználó a megadott előtervezési adatokra válaszul egy részletes paraméter listát kap az általa tervezendő fogaskerékhajtás kapcsolódó kerekeiről. Az alap program jelenleg már a teljes geometriai méretezést képes végrehajtani és az alámetszés veszélyét is vizsgálja, és jelzi, ha módosításra van szükség. A kapott adatok minden geometriai paramétert magukban foglalnak, melyet ezután fel lehet használni bármilyen más szimulációs szoftverben vagy számításban. A távolabbi cél a jelen program kiegészítése oly módon, hogy magában is képes legyen a fogazatok kap- 
csolódására vonatkozó szimulációkat végrehajtani. Modulárisan fejleszthető jellegéből adódóan bármilyen segédprogrammal bővíthető a meglévő rendszer a jövőbeli igényeknek megfelelően.

\section{A szoftverrel kapcsolatos megfontolások és célkitüzések}

A program tervezésekor elsődleges szempont volt a gyorsaság a kis erőforrás igény, és az operációs rendszerek közti hordozhatóság. Mivel ma már az okos eszközök az élet minden területén jelen vannak, alapelvárás, hogy a program akár egy okos mobilon is használható legyen, és a kapott adatokat bármely okos eszköznek át tudja adni. Ennek komoly előnye lenne a gyártási folyamatban a gyártás közbeni optimalizálás lehetőségének megteremtésével. A program maga tisztán $\mathrm{C}$ programkódot használ GTK3 keretrendszer modullal. A GTK3 modul lehetővé teszi nagy hatékonyságú grafikus felületek létrehozását. Ezt a modult Linux rendszerek fejlesztésére készítették és megírásukkor a cél az optimális és kis rendszerigényü programkód létrehozása volt. A szoftver csak szabványos C utasításokat és azokra épülő modulokat használ, így bármely operációs rendszerre könnyen lefordítható. A program által elvégzett számításokhoz szükséges algoritmusokat az ANSI/AGMA 2005-D3 szabvány [3] tartalmazza.

Célkitüzések:

- A főprogram feladata hypoid hajtások geometriai méretezése és ellenőrzése, melyet már sikeresen el tud végezni.

- További cél a gyártáshoz szükséges gépbeállítások számítására alkalmas modul létrehozása.

- Egy számoló és grafikus megjelenítő modul létrehozása a fogazatok kapcsolódási pontjainak meghatározására.

- Egy 3D grafikus megjelenítésre képes programmodul létrehozása, mely meg tudja jeleníteni a geometriai paraméterek módosítására bekövetkező változásokat a fogazatok felületén.

\section{A grafikus keretrendszer fejlesztéséről}

Az interaktív grafikus felület létrehozásához a GTK3 [1] modult használtam. Ez egy C nyelven írt funkciókból és programkódokból álló gyüjtemény, mely előre megírt rutinokat tartalmaz alapvető megjelenítési és adatbeviteli feladatok végrehajtására. A GTK3 a Linux operációs rendszerek paneljének megírására lett kifejlesztve, ahol a hatékonyság volt a legfontosabb szempont. Ezzel a kódgyüjteménnyel kompromisszum mentes grafikus felület hozható létre. Az általunk bemutatásra kerülő program nagyon alacsony RAM és CPU felhasználással dolgozik, és nagy sebességgel, köszönhetően a fent említett programozási elveknek. Elsőként a program Linux rendszer alá készült el. Ennek két fó oka, hogy a program ezen a rendszeren képes elérni a maximális teljesítményt, továbbá innen a legkönnyebb más operációs rendszerekre átírni a programot. További előny még, hogy a mai operációs rendszerek sok Linux kernelből átvett kódot implementáltak saját rendszereikbe, ezért nagyobb az átjárhatóság a rendszerek között. Egy másik fontos szempont, hogy az okos eszközök meghatározó hányada Android rendszert használt, ami a stabil Linux kernelre épül. Ez fontos szempont ha a későbbiekben elkészül az androidos változata a programnak.

\section{A Program tervezett felépítése}

Az 1. ábrán jól látható, hogy a program bármilyen szükséges funkcióval könnyen bővíthető.

A program főmodulja jelenleg félautomatikus. Nem képes önállóan adatokat importálni más eszközökről és azokat önállóan feldolgozni, továbbá néhány a számításhoz szükséges konstanst még nem 
tud automatikusan beilleszteni a számítási menetbe. A legtöbb konstanst már beilleszti az automata kereső funkció. Ez a terület még további fejlesztési lehetőséget rejt magában.



1. ábra. Jelen és jövöbeli fejlesztés programvázlata

A számítási eljárás teljesen rugalmas. Ezt azzal éri el a szoftver, hogy a bevitt adatok bármelyike a többitől függetlenül módosítható, és nem szükséges minden adatot biztosítani. Minden olyan számítást, amihez a megadott adatok elegendőek, elvégez a program. Ha rendelkezésre áll elég adat hozzá, akkor ellenőriz is. Ez lehetővé teszi rész-számítások elvégzését, így csak a ténylegesen szükséges geometriai adatokra is leszükíthető a kalkuláció. Mivel az adatok bármelyike a többitől függetlenül adható meg vagy módosítható akár menet közben is, ezért lehetőség van nagy számú tervezési variáció kipróbálására. Az adatbeviteli mezők a programból való kilépésig vagy a felhasználó általi módosításig minden adatot átmenetileg tárolnak ezzel szükségtelenné téve az ismételt adatbevitelt ha új számítást vagy egy módosított kalkulációt akarunk készíteni. Ez a programfunkció egyfelől gyorsítja az új variációk létrahozását, másrészről lehetőséget biztosít a paraméterek változtatásának a geometriára gyakorolt hatásának vizsgálatára.

Ezzel már egyfajta előoptimalizálást végezhetünk a geometriai paraméterekre vonatkozóan, hogy az alapvető konstrukciós hibalehetőségeket kiszürjük.

\section{A Program müködésének szemléltetése}

A beviteli adatmezőt és a számítási adatlapot a következő ábrán mutatjuk be. Az ábrán látható beviteli adatok egy referenciaszámításhoz tartoznak, melyekkel a program müködését teszteltem. A referencia és tesztadatok számítását Dr. Szente József készítette, melyet ezúton is köszönök. 


\begin{tabular}{|c|c|c|c|c|c|}
\hline & & Gea & ar Designer ver: 0.003 beta & & \\
\hline Fogazat típus: & & mG:1,034483 mm & Lábszögek összegének számítá & $\psi \circ \mathrm{O}: 39,462388$ & \\
\hline Fogszám n: & 29 & $\mathrm{~d}: 138,939000 \mathrm{~mm}$ & $\Sigma \delta \mathrm{D}: 0,000000$ & Középsô normál foghúrméret: & \\
\hline Fogszám N: & 30 & $\mathrm{D}: 143,730000 \mathrm{~mm}$ & $\delta P: 0,000000$ & tnc:5,950565 & \\
\hline Külső homlokmodul mte: & 4,791 & p: 15,051372 & $\delta G: 0,000000$ & Tnc:5,859191 & \\
\hline Fogszélesség F: & 40 & $\gamma: 17,193812$ & Fejkúpszög számítása & Húrméret mérömagassága: & \\
\hline Tengelyszög $\Sigma:$ & 35 & Г:17,806188 & v0:17,193812 & acP:3,933349 & \\
\hline Foghajlásszög $\Psi:$ & 30 & Am:215,007943 & Lábkúpszög számítása & Pw : 2,357652 & \\
\hline Fogmagasság tényezö k1: & 2 & rc: 107,503982 & VR:17,193812 & Alámetszés ellenörzése & \\
\hline Lábhézag tényező k2: & 0,15 & $h: 7,592045$ & rR:17,806188 & AiG:195,007943 & \\
\hline Külsõ normál foghézag B: & 0,13 & c:1,138807 & Külsô fejmagasság számítása & 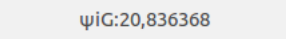 & \\
\hline & & 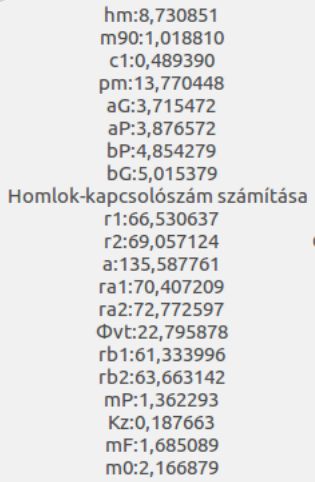 & 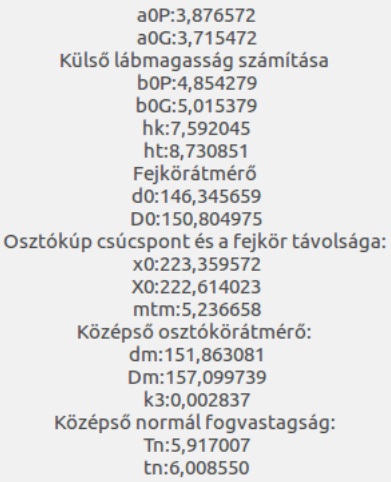 & $\begin{array}{c}\text { ФTi:21,277906 } \\
\text { bilP: } 7,946469 \\
\text { biP:4,854279 } \\
\text { Nincs alámetszés }\end{array}$ & \\
\hline & & & & & cula \\
\hline
\end{tabular}

\section{2. ábra. A geometriai méretezöprogram müködés közben}

Az ábrán látható baloldali oszlop az adatbeviteli rész a megadott teszt adatsorral. A következő 3 oszlop a kis és nagykerék fogazataira vonatkozó számított geometriai adatokat tartalmazza. A fogazattípus adatmező jelenleg még nem használható. Azt igény esetén bővíteni fogjuk más fogazattípusok vizsgálatára is.

\section{6. Összefoglalás}

Az általunk tervezett szoftver egy sokoldalúan használható eszköz, mely hatékonysága és OP rendszer függetlensége miatt széles körben használható eredményesen. Remélhetőleg a jövőben lehetőség lesz az analitikai modulok továbbfejlesztésére, hogy egy komplett tesztszoftvert alkossunk meg.

\section{Köszönetnyilvánítás}

Szeretnék köszönetet mondani Dr. Szente Józsefnek a program tesztadatsorának elkészítéséért és a program számításaihoz szükséges elméleti alapok lefektetésében nyújtott felbecsülhetetlen segítségéért.

A cikkben ismertetett kutató munka az EFOP-3.6.1-16-2016-00011 jelű „Fiatalodó és Megújuló Egyetem - Innovatív Tudásváros - a Miskolci Egyetem intelligens szakosodást szolgáló intézményi fejlesztése" projekt részeként - a Széchenyi 2020 keretében - az Európai Unió támogatásával, az Európai Szociális Alap társfinanszírozásával valósul meg. 


\section{Irodalom}

[1] Gnome Developer Homepage (GTK3 codebase) 2019.09.03.

https://developer.gnome.org/gtk3/stable/gtk-getting-started.html\#id-1.2.3.5

[2] C code library and syntax help 2019.09.03.

https://www.tutorialspoint.com/c_standard_library/index.htm

[3] ANSI/AGMA 2005-D3 Standards

[4] CodeBlocks reference and manuals 2019.09.03.

http://www.codeblocks.org/

[5] Reiter, I.: C programozás lépésről lépésre, Jedlik Oktatási Stúdió Kft. 2018., ISBN: 9786155012174

[6] Wagner, B.: Hatékony C, Kiskapu Kft. 2005., ISBN:9789639301948 